\title{
Density-dependent expression of plasticity in larval morphology: effects of actual and apparent competitors
}

\author{
Suzanne E. Kacenas, Robert D. Podolsky* \\ Grice Marine Laboratory, Department of Biology, College of Charleston, Charleston, SC 29412, USA
}

\begin{abstract}
Larvae of several marine invertebrates are known to alter their morphology adaptively as a response to changes in conditions, such as food and predator density, within plankton communities. In contrast, nothing is known about plastic responses to the density of competitors, which could signal the potential for food limitation or predation risk. We studied effects on trophic morphology of culturing sand dollar pluteus larvae with limiting or saturating food and at low or high density using 1 of 3 potential competitors: feeding conspecifics, feeding heterospecifics, and non-feeding heterospecifics. We hypothesized that feeding competitors would induce a morphological response similar to limiting food, while the effect of non-feeders would depend on whether larvae respond directly to higher density or indirectly to food reduction. Plutei cultured with limited food grew longer feeding arms and shorter stomachs, though only in higher density treatments. Whereas the response to food involved a tradeoff between skeleton and stomach growth, larvae responded to high density by increasing investment in both, reflecting a more complex set of energetic tradeoffs. Similar responses to the presence of feeding and non-feeding larvae implicate a sensory mechanism involving signals from potential competitors rather than a food decline. Patterns in 2 literature surveys of laboratory experiments and field studies suggest that culture density is a critical but neglected aspect of experimental design in the study of early life-history stages. Larvae are most likely exposed to densities sufficient to induce plasticity following synchronous spawning, highlighting the importance of natural history in understanding density-dependent effects on developmental plasticity.
\end{abstract}

${ }^{*}$ Corresponding author: podolskyr@cofc.edu

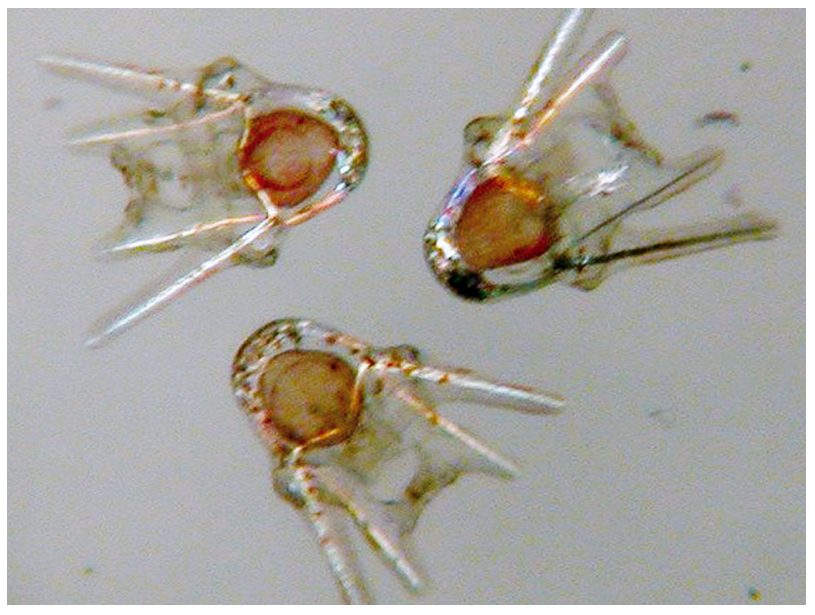

In sand dollar (Dendraster excentricus) larvae, the plasticity of feeding arm growth in response to food ration depends on the density of potential competitors

Photo: Jason Hodin

KEY WORDS: Invertebrate - Larvae - Plankton · Competition · Density-dependent $\cdot$ Marine $\cdot$ Tradeoff $\cdot$ Feeding $\cdot$ Experimental design

\section{INTRODUCTION}

Competition leads to a change in resource levels that can influence individual survival and reproduction. As a result, competition can drive evolutionary change in phenotypes through selection on trait values (e.g. character displacement; Pfennig \& Pfennig 2010) or on their plasticity (Burns \& Strauss 2012,

() The authors 2018. Open Access under Creative Commons by Attribution Licence. Use, distribution and reproduction are unrestricted. Authors and original publication must be credited. 
Scheiner et al. 2015). The evolution of traits or plasticity for traits involved in competition would require that populations be controlled chronically or intermittently, respectively, by the resources for which they compete. Plasticity, in particular, is most likely to evolve in response to coarse-grained heterogeneity in the competitive landscape (Levins 1968, Hollander 2008).

The evolution of adaptive plasticity also requires a mechanism for sensing conditions under which a given phenotype is beneficial. In the case of competition, sensory input could involve direct assessment of the densities of potential competitors or indirect assessment of changes in resource levels. Such sensory mechanisms can be energetically costly (Futuyma \& Moreno 1988) and there may be other costs or limits associated with the capacity to produce multiple phenotypes or the risk of producing an inappropriate one (DeWitt et al. 1998).

In communities of planktonic grazers, competition for food is limited to times and places where zooplankton are concentrated for long enough to impact levels of phytoplankton. Species that engage in aggregate spawning, for example, can experience elevated densities during the early larval period (Jørgensen 1981, Emlet 1986), with a potential impact on food supply (Bos et al. 2006). Likewise, temporary concentration of zooplankton can be promoted by physical factors, including tides, currents, and wind (DeWolf 1973, Cronin \& Forward 1986, Blukacz et al. 2010), and by biological factors (Folt \& Burns 1999), such as aggregation in the presence of resources (Metaxas \& Young 1998) or preferred physical conditions (Pennington \& Emlet 1986, Civelek et al. 2013). These drivers could create temporal and spatial asynchrony in the abundance of zooplankton and phytoplankton (Rovinsky et al. 1997, Blukacz et al. 2010). The evolution of a plastic response to competition could be favored if such asynchrony persists on a time scale similar to the span of a larval stage. On the other hand, plasticity may not provide an adaptive response to variability if it cannot track more rapid fluctuations in competition or food availability (Miner \& Vonesh 2004). Marine invertebrate larvae have been a model for the study of adaptive plasticity because they have a specific life-history role in acquiring resources, and their feeding structures have functional properties that are well characterized. Plasticity of feeding structures has been demonstrated broadly among larvae of molluscan (bivalves: Strathmann et al. 1993; gastropods: Klinzing \& Pechenik 2000, Phillips 2011) and echinoderm classes (echinoids: summarized by Soars et al. 2009; asteroids:
George 1999, Wolfe et al. 2015; ophiuroids: Podolsky \& McAlister 2005; holothuroids: Morgan 2008, Sun \& Li 2013). Environmental heterogeneity that induces plasticity includes the mean (Hart \& Scheibling 1988, Strathmann et al. 1992, 1993, Sewell, et al. 2004) and variance (Miner \& Vonesh 2004) of food concentration as well as the presence of predator cues (Vaughn 2007). Pluteus larvae of echinoids, in particular, grow longer ciliated bands and skeletal supports in response to food scarcity (Boidron-Metairon 1988, Soars et al. 2009). Growth of longer arms is considered an adaptive response to food limitation, involving an energetic tradeoff in investment between the larval feeding apparatus and structures that are retained through metamorphosis (Strathmann et al. 1992, Miner 2005).

Because competition can result in food scarcity, the ability to respond adaptively to competitor density could similarly improve larval growth and survival (Relyea \& Auld 2005). However, nothing is known about morphological responses of marine invertebrate larvae to the density of competitors. Such information could be critical to interpreting laboratory experiments and field surveys (Fenaux et al. 1994). For example, larvae that are cultured at atypically high density could yield results that are inconsistent or that differ from those expected under field conditions (Johnson \& Shanks 1997). Conversely, if larvae can respond adaptively to the potential for food scarcity by detecting competitors, or if factors other than food concentration influence the size of feeding structures, then trying to infer the degree of food limitation from morphology in field-collected larvae could be problematic (Klinzing \& Pechenik 2000).

In laboratory experiments, we addressed the combined effects of varying food level and the density of actual or apparent competitors. In particular, we investigated (1) whether pluteus larvae of the sand dollar Dendraster excentricus (Eschscholtz) show plastic morphological responses to competition from conspecific larvae and from feeding heterospecific larvae, (2) whether such responses to competitors depend on food ration, and (3) whether larvae show a similar morphological response to the presence of non-feeding, and therefore non-competing, larvae. We used the latter comparison to infer whether the mechanism of response involved a direct assessment of larval density or an indirect assessment of food level. Finally, using 2 surveys of published literature, we evaluated (4) the ecological relevance of laboratory studies of plasticity in light of our results by comparing densities of experimental cultures to those measured in the plankton under field conditions. 


\section{MATERIALS AND METHODS}

\section{Collection and fertilization of eggs}

Adults of Dendraster excentricus and the purple sea urchin Strongylocentrotus purpuratus (Stimpson), species with feeding pluteus larvae, were induced to spawn via intracoelomic injection of $0.55 \mathrm{M}$ $\mathrm{KCl}$. Spawning was induced in the ribbed limpet Lottia digitalis (Rathke), a species with swimming but non-feeding veliger larvae, by allowing the seawater in which individuals were placed to warm to room temperature. Eggs of each of the 3 species were fertilized with unmeasured concentrations of dilute sperm. Embryos of each species were transferred separately to 1.51 jars containing 11 of $0.45 \mu \mathrm{m}$ filtered seawater (FSW) kept at $10-14^{\circ} \mathrm{C}$ in a sea table and stirred at 10 strokes min $^{-1}$ by a mechanical paddle system (Strathmann 1987). All experiments were started with $3 \mathrm{~d}$ old larvae of $D$. excentricus, $S$. purpuratus, and $L$. digitalis so that larvae were exposed to experimental food levels around the time that feeding began (Strathmann 1987).

\section{Algal culture and cell counts}

Algal cultures were established from stock cultures of the cryptophyte Rhodomonas lens (Pascher and Ruttner), which is used commonly in experiments as a food for echinoderm larvae (Strathmann 1987, Hart \& Strathmann 1994, Eckert 1998). All cultures were maintained at room temperature and under ambient light conditions. A hemocytometer on a compound microscope was used to measure algal stock concentrations. Algae were pelleted in a centrifuge at $1000 \mathrm{rpm}$ and resuspended in FSW before addition to larval cultures.

\section{Experimental design}

We cultured larvae of $D$. excentricus at 2 food levels and 4 treatments evaluating the effects of competition in a full factorial design. The 2 food levels, i.e. 250 (low, L) and 5000 (high, H) cells $\mathrm{ml}^{-1}$ of $R$. lens, were in a range similar to those used in previous experiments to induce plasticity in echinoid larvae (Boidron-Metairon 1988, Strathmann et al. 1992, Hart \& Strathmann 1994, Sewell et al. 2004). The competition treatments included 1 low density control and 3 higher density treatments using different competitors to augment density. Each of the 8 food level-competitor combinations had 5 replicates, for a total of 40 containers. Each container was a $150 \mathrm{ml}$ glass custard dish into which combinations of different larvae, food, and FSW were added, as described below, to a total volume of $100 \mathrm{ml}$. Water was changed and food was replenished every other day for the $5 \mathrm{~d}$ of the experiment.

Containers in the low competitor density controls each held 5 plutei of $D$. excentricus at a larval concentration of $0.05 \mathrm{ml}^{-1}$ in FSW. Containers in all other treatments also included the $5 \mathrm{D}$. excentricus but had a total larval concentration of $0.25 \mathrm{ml}^{-1}$ created by the presence of additional larvae. Containers in the conspecific treatments held 20 additional plutei of $D$. excentricus; those in the heterospecific feeding treatments held 20 plutei of $S$. purpuratus, and those in the heterospecific non-feeding treatments held 20 veligers of $L$. digitalis. All containers were placed in a random array in a sea table $\left(12-14^{\circ} \mathrm{C}\right)$ and mechanically stirred with a paddle at 10 strokes $\mathrm{min}^{-1}$. Maximum clearance rates per larva for both feeding species at these developmental stages are around $3 \mathrm{ml}$ $\mathrm{d}^{-1}$ (Hart 1996). This value suggests that 5 feeding larvae likely would not significantly deplete their food supply, especially considering the contribution of phytoplankton reproduction to algal concentrations (Strathmann 1996), whereas 25 feeding larvae in the higher density treatments likely would.

\section{Data collection and analysis}

After $5 \mathrm{~d}$ in experimental culture (8 d after fertilization), all surviving plutei of $D$. excentricus were removed and measured, except for the treatment containing 25 conspecifics, from which 5 plutei of $D$. excentricus were subsampled at random. This time point was used because morphological differences between constant food levels are often most apparent sometime around Days 4 through 8 of development (see Podolsky \& McAlister 2005). Differences in stage for a fixed sampling age can complicate interpretations when change in a quantitative variable (e.g. growth) is altered by stage transitions (Pörtner et al. 2010); the period we focused on involves regular, linear arm growth and no major qualitative transitions (e.g. rudiment formation or metamorphosis). Losses of larvae from water changes or mortality were low, with a total recovery of $81 \%$. Standard measures of body size (McEdward 1986, Miner 2005), i.e. postoral rod length (PORL, a proxy for ciliary band length), body length $(\mathrm{BL}$, measured from the posterior tip to the tissue bridge between the anterolateral arms, as 
an estimate of overall size), and stomach length (SL), were recorded for larvae in a ventral-down position at $200 \times$ to the nearest $5 \mu \mathrm{m}$ using a compound microscope and an ocular micrometer (Fig. 1). In this position, the measured features lie in the focal plane.

A linear mixed-effects model in SPSS (v.24) was used to analyze the effect of treatment on each of the larval measurements, with container as a random effect and competitor type and food ration as fixed effects. Analyses were run with and without BL as a covariate in order to compare both absolute and relative sizes of arms and stomachs. To evaluate the effect of density alone, planned contrasts were used to compare the high density treatments to the low density treatment. Non-significant interactions with the covariate were removed. Phenotypic correlations between arm length and SL were estimated within each food-competitor treatment using container as a random effect. Measurements were log transformed to meet assumptions of the analysis. Estimated marginal means \pm SE were calculated from the mixed-effects model and compared using a sequential Bonferroni adjustment (Holm 1979) for multiple comparisons.

\section{Literature surveys}

We performed 2 surveys of published literature to evaluate the ecological relevance of densities used in past laboratory assays of plasticity in response to food availability. First, we searched exhaustively, using databases and literature cited sections, for studies that measured morphological differences in marine invertebrate larvae reared in the laboratory under different food levels, noting the culture density used and whether plasticity of feeding structures was

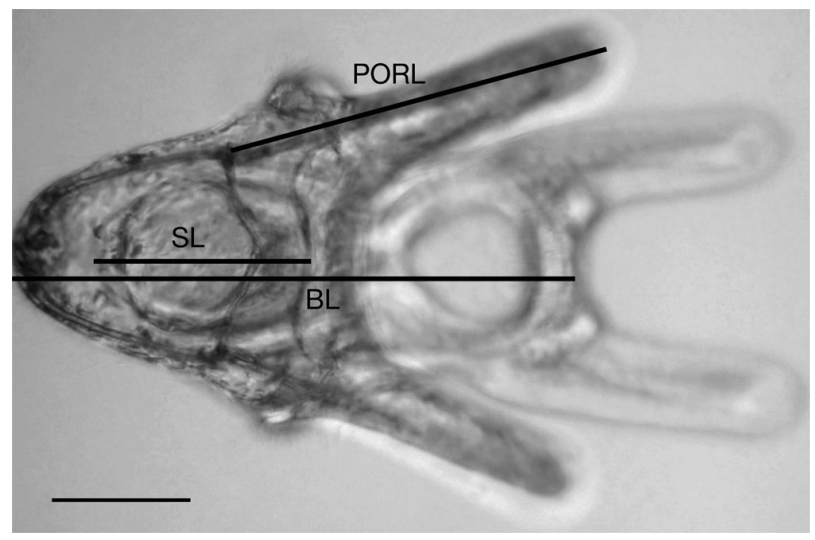

Fig. 1. Measurements of echinoplutei of Dendraster excentricus used in the study: postoral rod length (PORL), stomach length (SL), and body length (BL). Scale bar is $100 \mu \mathrm{m}$ found. We omitted studies where cloning frequency was the morphological response because they did not deal explicitly with the relative size of the feeding apparatus (although cloning may be a method of increasing feeding capacity of the genet). We report initial culture densities, recognizing that density sometimes declined during experiments as a result of sampling or mortality.

Second, we used search terms that combined 'meroplankton' or 'mesozooplankton' (categories to which the study species belong) with 'density or abundance' in Web of Science to locate field studies reporting zooplankton densities that could be extracted from tables and figures. We report information from each study that yielded such data, except for 2 from highly eutrophied waters that were studied for effects of pollution. Beyond those searches we did not attempt to be exhaustive, but rather to generate a representative and unbiased sample that included tropical, temperate, and polar examples. In addition to providing the maximum and minimum density values reported anywhere in each study, we also estimated an average value across all of the data presented in the study.

\section{RESULTS}

\section{Laboratory experiments}

Both larval density and food level influenced the growth of the skeleton and stomach of Dendraster excentricus plutei. Competitor treatment had a significant effect on postoral arm length $\left(F_{3,31.4}=9.57, \mathrm{p}<\right.$ 0.001 ), with the production of longer postoral rods at each of the higher densities regardless of whether density was increased by the addition of conspecific larvae, feeding heterospecific larvae, or non-feeding heterospecific larvae (Fig. 2A). As expected, plutei also produced longer postoral rods in response to low food level, though only at the higher larval densities. Increased investment in the food-collecting structure in the presence of limiting food, but only under high actual or apparent competition, was reflected in a significant interaction between larval density and food level $\left(F_{1,35.4}=6.76, \mathrm{p}=0.013\right)$. Results were similar when controlling for body size: postoral rods were relatively longer for a given $\mathrm{BL}$ at the higher larval densities $\left(F_{3,153.7}=8.77, \mathrm{p}<0.001\right)$ and there was a significant increase in PORL under low food conditions $\left(F_{1,38.9}=9.42, \mathrm{p}=0.004\right)$, although the density by food interaction was marginally non-significant $\left(F_{1,41.9}=3.39, \mathrm{p}=0.073\right)$. At low larval density, arm 

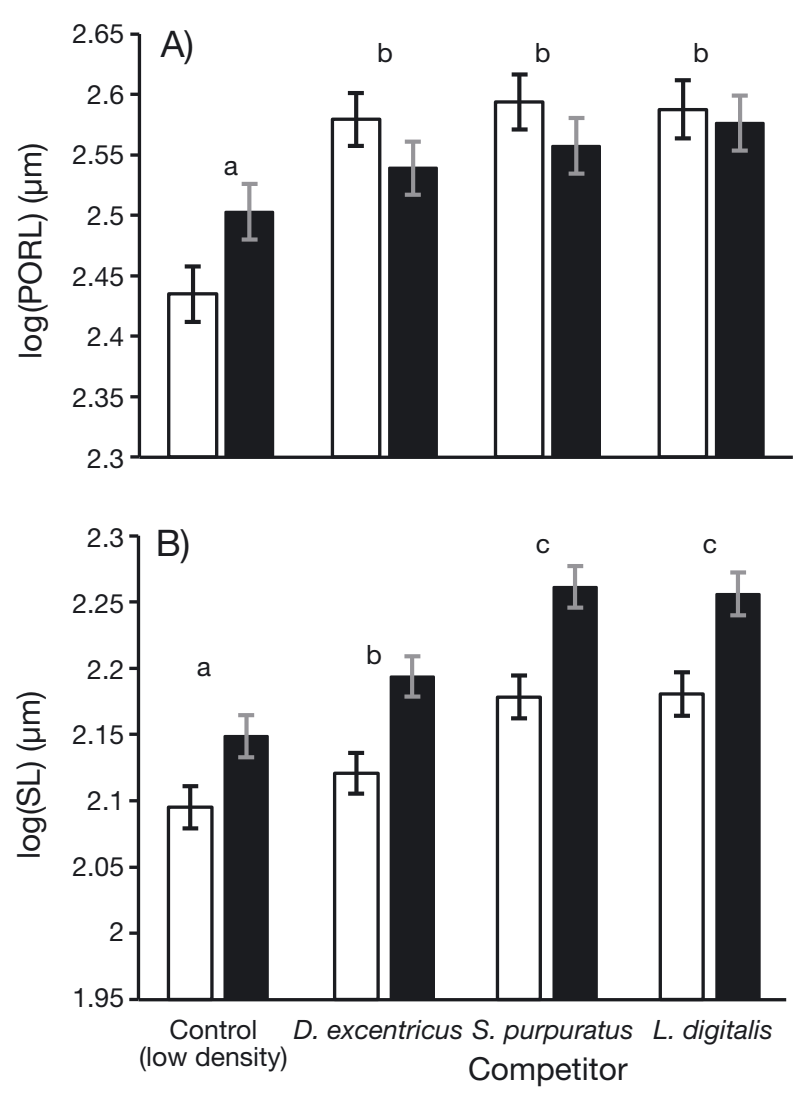

Fig. 2. Effects of competition and food level on the absolute lengths of (A) postoral arm rods (PORL) and (B) stomach length (SL) $8 \mathrm{~d}$ post fertilization in Dendraster excentricus. Bars show mean \pm SE for low food (white bars) and high food (black bars) conditions. Low density controls $\left(0.05 \mathrm{ml}^{-1}\right)$ contained only larvae of $D$. excentricus; in each of the other 3 treatments, density was increased $\left(0.25 \mathrm{ml}^{-1}\right)$ by addition of competitors, either conspecific feeding larvae $(D$. excentricus), heterospecific feeding larvae (Strogylocentrotus purpuratus), or heterospecific non-feeding larvae (Lottia digitalis). Different lowercase letters denote significant differences among competition conditions

length controlling for body size was similar between food levels, whereas at high larval densities the difference between food levels increased (Fig. 3A).

SL was also significantly influenced by competition treatment $\left(F_{3,28.1}=15.83, \mathrm{p}<0.001\right)$ and similarly increased in each of the higher larval density treatments, although the increase was greater for the 2 heterospecific treatments than for the conspecific treatment (Fig. 2B). SL was also significantly and positively related to food level $\left(F_{3,153.7}=8.77, \mathrm{p}<\right.$ 0.001 ), and there was no food by competitor interaction $\left(F_{3,28.1}=0.28, \mathrm{p}=0.84\right)$. SL controlling for $\mathrm{BL}$ showed similar patterns as absolute SL, except that SL did not differ significantly between the low density treatment and the high density treatment involving conspecifics (Fig. 2B).
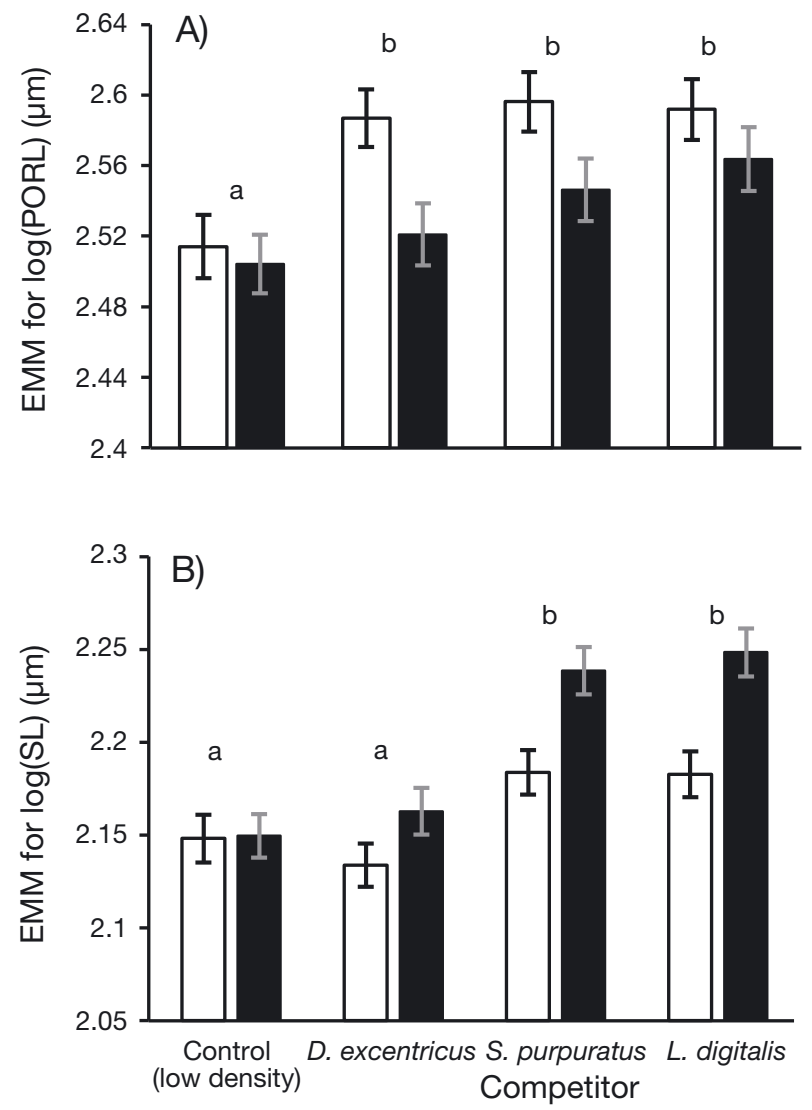

Fig. 3. Effects of competition and food level on the lengths of (A) postoral arm rods (PORL) and (B) stomach (SL) controlling for body size $8 \mathrm{~d}$ post fertilization in Dendraster excentricus. Bars show estimated marginal mean (EMM) \pm SE for low food (white bars) and high food (black bars). Different lowercase letters denote significant differences among competition conditions. Other information as in Fig. 2

Within each of the 8 competition by food combinations, individual larvae showed a positive phenotypic correlation between PORL and SL (Fig. 4A; overall effect of $\log$ SL on $\log$ PORL: $F_{1,161.5}=20.21, \mathrm{p}<$ $0.001)$, likely reflecting differences in overall size of individual larvae. In contrast, PORL and SL exhibited an inverse relationship between food treatments, though only for each of the 3 high density treatments (Fig. 4B), which is consistent with the expected tradeoff in investment in these 2 larval features.

\section{Literature surveys}

A survey of previous laboratory studies of morphological plasticity found that densities at which invertebrate larvae were tested were typically high and varied over nearly 2 orders of magnitude (Table 1). Only 10 of 42 previously published experiments used 

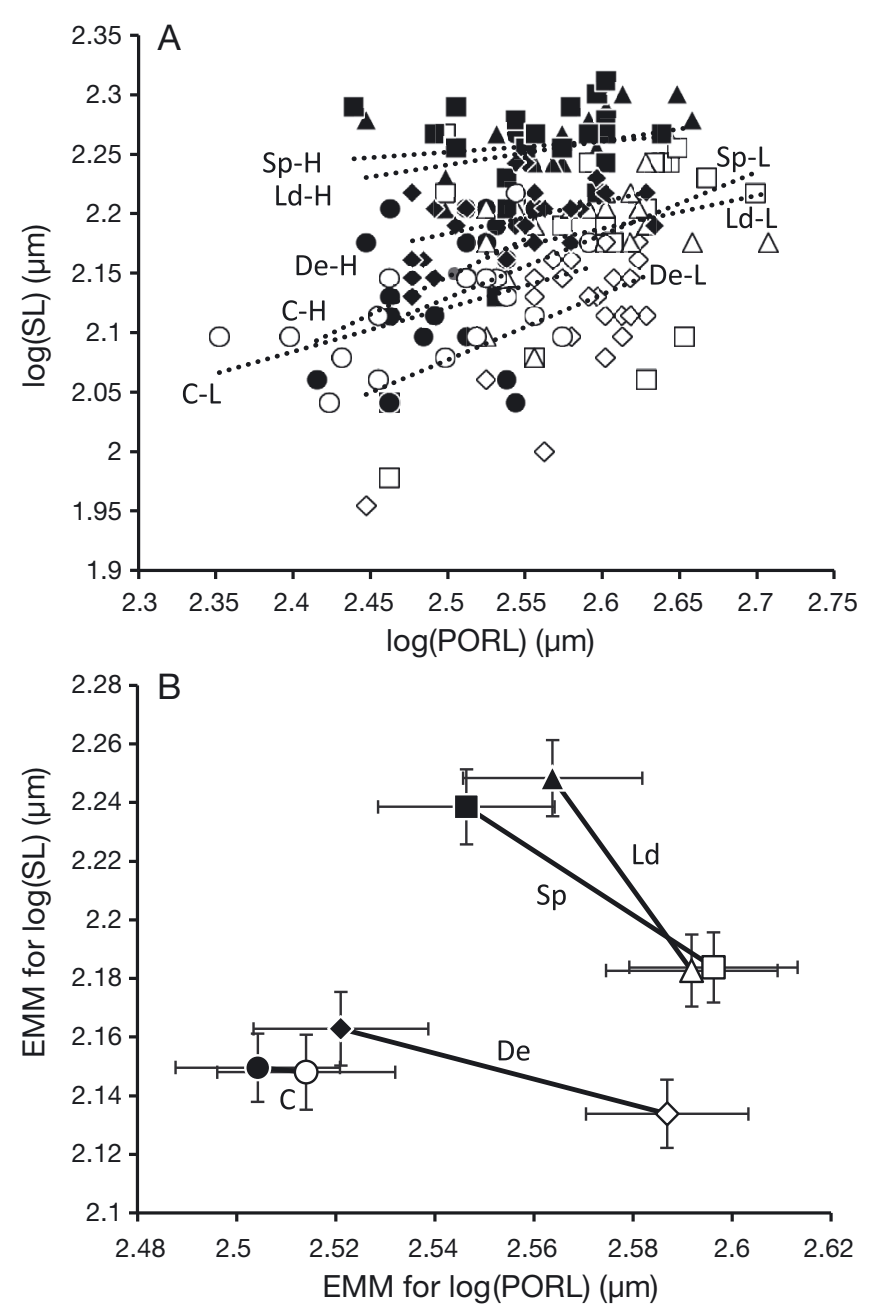

Fig. 4. (A) Relationship between postoral rod length (PORL) and stomach length (SL) between individual Dendraster excentricus larvae. The regression lines reflect positive relationships between the 2 measures separated by treatment (see 'Materials and methods' for treatment details). (B) Estimated marginal means $(E M M) \pm S E$ for PORL and SL controlling for body size across the 8 treatments, showing the tradeoff in investment between food levels. Error bars are $1 \mathrm{SE}$. Circle = low density control $(\mathrm{C})$; diamond $=D$. excentricus $(\mathrm{De}) ;$ square $=$ Strongylocentrotus purpuratus $(\mathrm{Sp})$; triangle $=$ Lottia digitalis $(\mathrm{Ld})$. Filled symbols $=$ high food level $(\mathrm{H})$; open symbols = low food level $(\mathrm{L})$

densities that were lower than our high density treatment $\left(0.25 \mathrm{ml}^{-1}\right)$, and none was as low as our low density $\left(0.05 \mathrm{ml}^{-1}\right)$. A majority were around $1 \mathrm{ml}^{-1}$, possibly by convention, with one value as high as $5 \mathrm{ml}^{-1}$. There was no significant difference in average culture density between experiments that did $(0.92 \pm$ $\left.0.21 \mathrm{ml}^{-1}\right)$ and did not $\left(0.85 \pm 0.12 \mathrm{ml}^{-1}\right)$ show an effect of food level on plasticity $\left(t_{39}=1.68, \mathrm{p}=0.38\right)$.

Densities of natural zooplankton reported in a representative sample of field studies, on the other hand, were consistently lower than those used in laboratory studies (Fig. 5). Densities varied more within than between regions $\left(F_{2,23}=0.187, \mathrm{p}=0.19\right)$. Within studies, average values were as high as $0.01 \mathrm{ml}^{-1}$, and spatial or temporal samples varied by as much as 3 orders of magnitude. The maximum value for any sample reported in any of the studies was $0.1 \mathrm{ml}^{-1}$, although the average value for that study was only around $0.001 \mathrm{ml}^{-1}$ and it was the only study that reported any value higher than our low culture density of $0.05 \mathrm{ml}^{-1}$. A publication for the region where this study was conducted (Chester et al. 1980) reported densities that were 2 to 3 orders of magnitude lower than those used in laboratory experiments on larval plasticity.

\section{DISCUSSION}

As in previous studies, plutei of Dendraster excentricus were morphologically plastic in response to variation in food supply (Boidron-Metairon 1988, Fenaux et al. 1994, Hart \& Strathmann 1994). Arm elongation is considered an adaptive response to food limitation because a longer ciliated band increases the rate of suspension feeding (Hart \& Strathmann 1994, Hart 1996). We found, however, that this response to food was modulated by the density of larvae. Low density caused a reversal between food levels in the relative growth of the postoral arms, such that longer arms were produced under high food at low larval density but under low food at high larval density. This interaction likely reflects a balance of 2 processes that is unique to the developmental plasticity of feeding structures: a greater overall scope for growth of such structures when food is abundant versus the greater differential allocation of investment to feeding structures when food is limiting. This balance can influence the time during development when plasticity is most apparent in experiments with constant food levels - in many cases during a limited window before nutrient acquisition or morphogenesis masks differential allocation (Podolsky \& McAlister 2005). (The scope for a plastic response can persist, however, as demonstrated in experiments where food limitation is first imposed later in development; Hodin et al. 2016). Our results suggest that interactions among individuals affect how these 2 growth processes regulate the expression of plasticity in feeding structures.

In addition to the interaction between food and larval density, we found that density alone had a significant effect on arm length. The functional consequence of the response to higher density-an in- 
Table 1. Larval densities $\left(\mathrm{ml}^{-1}\right)$ in 42 experimental tests of the effect of food ration on plasticity of feeding structures in marine invertebrate larvae. 'AP' shows whether plasticity consistent with an adaptive response (larger structures at lower food levels) was detected (Y: yes, N: no). Densities used in the current study were 0.05 (low) and $0.25 \mathrm{ml}^{-1}$ (high). Ten values below our high density level are highlighted in bold. Miner \& Vonesh (2004) varied daily variance rather than mean ration

\begin{tabular}{|c|c|c|c|c|}
\hline Class & Species & Density & $\mathrm{AP}$ & Source \\
\hline \multirow[t]{2}{*}{ Asteroidea } & Acanthaster planci & 1 & $\mathrm{Y}$ & Wolfe et al. (2015) \\
\hline & Pisaster ochraceous & 0.33 & $\mathrm{Y}$ & George (1999) \\
\hline Bivalvia & Crassostrea gigas & 1.1 & $\mathrm{Y}$ & Strathmann et al. (1993) \\
\hline \multirow[t]{31}{*}{ Echinoidea } & Centrostephaus rodgersii & 0.25 & $\mathrm{~N}$ & Soars et al. (2009) \\
\hline & Clypeaster subdepressus & 0.25 & $\mathrm{Y}$ & Reitzel \& Heyland (2007) \\
\hline & Dendraster excentricus & 0.2 & $\mathrm{Y}$ & Hart \& Strathmann (1994) \\
\hline & & 0.25 & $\mathrm{Y}$ & Boidron-Metairon (1988) \\
\hline & & 2 & $\mathrm{Y}$ & Miner (2007) \\
\hline & Diadema antillarum & 1 & $\mathrm{~N}$ & McAlister (2008) \\
\hline & Diadema mexicanum & 1 & $\mathrm{~N}$ & McAlister (2008) \\
\hline & Echinometra anbrunti & 1 & $\mathrm{~N}$ & McAlister (2008) \\
\hline & Echinometra lucunter & 1 & $\mathrm{~N}$ & McAlister (2008) \\
\hline & Echinometra viridis & 1 & $\mathrm{~N}$ & McAlister (2008) \\
\hline & Encope michelini & 0.067 & $\mathrm{~N}$ & Eckert (1995) \\
\hline & Eucidaris thouarsi & 1 & $\mathrm{~N}$ & McAlister (2008) \\
\hline & Eucidaris tribuloides & 1 & $\mathrm{~N}$ & McAlister (2008) \\
\hline & Evichinus chloroticus & 2 & $\mathrm{Y}$ & Sewell et al. (2004) \\
\hline & Heliocidaris tuberculata & 0.25 & $\mathrm{Y}$ & Soars et al. (2009) \\
\hline & Leodia sexiesperforata & 0.25 & $\mathrm{~N}$ & Reitzel \& Heyland (2007) \\
\hline & Lytechinus variegatus & 0.067 & $\mathrm{Y}$ & Boidron-Metairon (1988) \\
\hline & & 0.19 & $\mathrm{Y}$ & McEdward \& Herrera (1999) \\
\hline & & 0.25 & $\mathrm{Y}$ & Miner \& Vonesh (2004) \\
\hline & Mellita tenuis & 0.25 & $\mathrm{Y}$ & Reitzel \& Heyland (2007) \\
\hline & Paracentrotus lividus & 0.063 & $\mathrm{Y}$ & Strathmann et al. (1992) \\
\hline & & 2 & $\mathrm{~N}$ & Garcia et al. (2015) \\
\hline & Strongylocentrotus droebachiensis & 0.13 & $\mathrm{~N}$ & Hart \& Scheibling (1988) \\
\hline & & 0.13 & $\mathrm{Y}$ & Bertram \& Strathmann (1998) \\
\hline & & 1 & $\mathrm{~N}$ & Meidel et al. (1999) \\
\hline & Strongylocentrotus franciscanus & 1 & $\mathrm{Y}$ & McAlister (2007) \\
\hline & & 2 & $\mathrm{Y}$ & Miner (2005) \\
\hline & Strongylocentrotus purpuratus & 1 & $\mathrm{Y}$ & McAlister (2007) \\
\hline & & 2 & $\mathrm{Y}$ & Miner (2007) \\
\hline & & 2 & $\mathrm{Y}$ & Miner (2005) \\
\hline & Tripneustes gratilla & 5 & $\mathrm{Y}$ & Byrne et al. (2008) \\
\hline \multirow[t]{2}{*}{ Gastropoda } & Crepidula fornicata & 0.18 & $\mathrm{Y}$ & Klinzing \& Pechenik (2000) \\
\hline & Dendropoma maximum & 0.1 & $\mathrm{Y}$ & Phillips (2011) \\
\hline \multirow[t]{2}{*}{ Holothuroidea } & Astichopus japonicus & 0.15 & $\mathrm{Y}$ & Sun \& Li (2013) \\
\hline & Australostichopus mollis & 1 & $\mathrm{Y}$ & Morgan (2008) \\
\hline \multirow[t]{4}{*}{ Ophiuroidea } & Macrophiothrix caenosa & 1 & $\mathrm{~N}$ & Podolsky \& McAlister (2005) \\
\hline & Macrophiothrix koehleri & 1 & $\mathrm{Y}$ & Podolsky \& McAlister (2005) \\
\hline & Macrophiothrix longipeda & 1 & $\mathrm{Y}$ & Podolsky \& McAlister (2005) \\
\hline & Macrophiothrix rhabdota & 1 & $\mathrm{~N}$ & Podolsky \& McAlister (2005) \\
\hline
\end{tabular}

crease in the length of the ciliated band used in food collection-is consistent with our prediction that larvae would respond in similar ways to food scarcity and competition. In contrast, Relyea (2004) found an opposite effect of density on plasticity: in wood frogs, lower tadpole density was associated with greater plasticity of tail depth in response to predator number. This contrast can be explained by the difference in what density signals about predation versus competition: high density indicates diluted predation risk (Guariento et al. 2015) but increased competition risk. The pattern we observed could have involved a response either directly to the presence of potential competitors or indirectly to a reduction in food by competitors. The fact that arm rods lengthened even in the presence of non-feeding larvae suggests that a change in density alone was sufficient to trigger plasticity. As noted earlier, we focused on an early developmental window where plasticity tends to be most apparent; future work will examine whether the timing or duration of this window is density-dependent. 


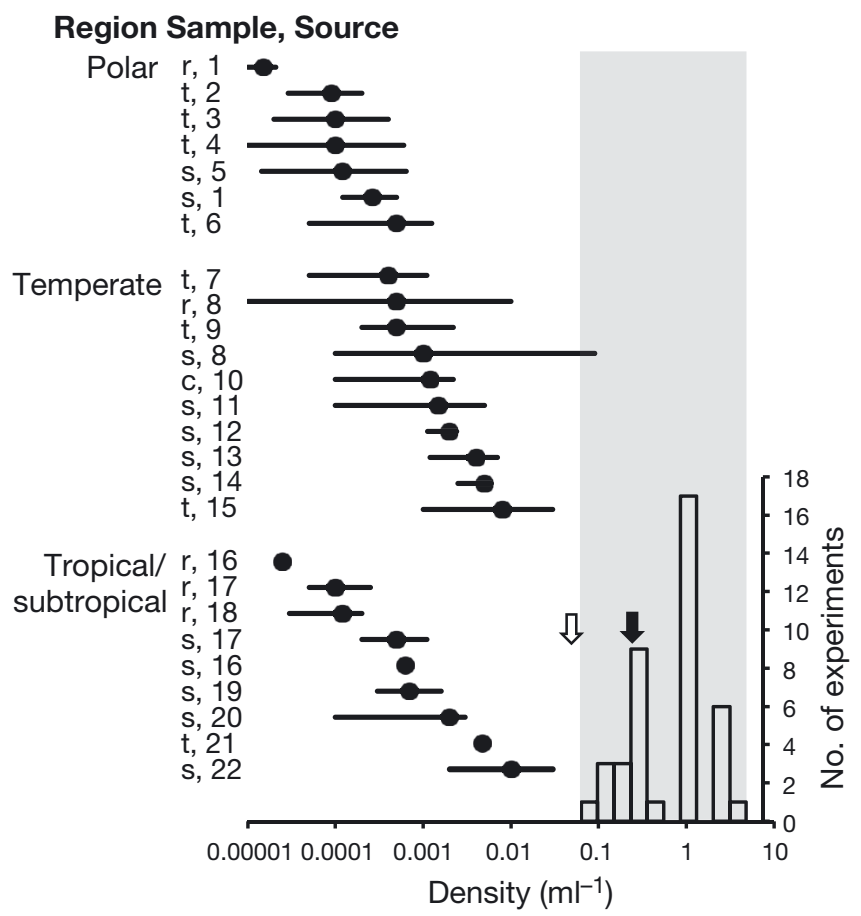

Fig. 5. Natural zooplankton densities from a selection of 22 field studies, arranged by geographic region in increasing order of average density (left side). Thick lines show the range from the minimum non- 0 value to the maximum value reported in each study, and circles are approximated average values. Missing lines indicate that only averages were reported. All values were estimated from data graphs. The grey area (right side) bounds the range of densities used in previous laboratory tests of larval plasticity, and the histogram shows the distribution of densities among those tests (data from Table 1). Arrows show the position of densities used in this study for low (open) and high (filled) food levels. The zooplankton fraction sampled as reported by each study is indicated as follows: $\mathrm{c}=$ copepods only; $\mathrm{r}=$ meroplankton, $\mathrm{s}=$ mesozooplankton, $\mathrm{t}=$ total zooplankton. Sources: 1 . Defren-Janson et al. (1999); 2. Hunt et al. (2002); 3. Pakhomov \& Froneman $(2004) ; 4$. Takahashi et al. $(2010) ; 5$. Stevens et al. (2015); 6. Hunt \& Hosie (2006); 7. Primo et al. (2009); 8. D'Elbee \& Castel (1995); 9. Marques et al. (2009); 10. Chester et al. (1980); 11. Rodriguez et al. (2000); 12. Purcell (2003); 13. Thompson et al. (2008); 14. Menendez et al. (2012); 15. Lonsdale \& Coull (1977); 16. Avila et al. (2009); 17. Neumann-Leitao et al. (2008); 18. Koettker \& Lopes (2013); 19. Tseng et al. (2011); 20. Cornils et al. (2007); 21. Hsieh et al. (2010); 22. Araujo et al. (2008)

Also consistent with previous studies (Strathmann et al. 1992, George 1999, Sewell et al. 2004, Miner 2005), we found that larvae cultured at higher food levels grew larger stomachs. The size of the stomach impacts juvenile growth by storing energy through metamorphosis (Okazaki 1975), unlike the ciliated band used in food collection (Burke 1981). Relative investment in these 2 structures is therefore viewed as part of a tradeoff that favors faster development through metamorphosis when food is abundant and investment in food-collecting structures when food is limited. Improving the rate of food collection can enhance larval survival by accelerating planktonic growth, though potentially at a cost to energy storage (Adams et al. 2011) that can be manifested at metamorphosis. For example, larvae of $D$. excentricus raised under food limitation increased their capacity for food collection but metamorphosed as smaller juveniles (Hart \& Strathmann 1994), which could increase the risk of benthic predation or limit the range of benthic foods (Allen 2008). Miner (2005) found support for the energetic basis of this tradeoff in a strong negative correlation between larval arm length and SL across food levels in strongylocentrotid sea urchins. We found similar evidence for this tradeoff, but again only in treatments with high larval densities, supporting the hypothesis that interactions among individuals can influence energy allocation.

On the other hand, stomach length responded positively to larval density, contrary to our expectation of similar responses to food scarcity and competition. Moreover, absolute stomach length showed a greater response to the presence of heterospecifics than conspecifics. This difference indicates that plasticity is sensitive not only to the density, but also the composition of the planktonic community. Stomach lengthening under high density could involve accelerated investment in post-larval structures in a crowded planktonic environment. (It is also possible that a change in stomach length is a non-adaptive response to culture conditions, for example, changes in water quality.) Bouchard et al. (2016) demonstrated a similar increase in relative gut size for bullfrog larvae when raised at high density, a trait that persists through metamorphosis as in echinoderms. However, in their study, other storage organs were correspondingly smaller at high density, indicating that stomach size alone might not reflect the complete set of energetic tradeoffs involved in a plastic response. Although it appears from our results that larvae invest in more rapid stomach growth under high density conditions, the potential cost of this investment is unknown. In addition to being appropriate for a particular environment, the expression of an adaptive plastic response requires a mechanism for transducing environmental signals (DeWitt et al. 1998). Cues available to detect an increase in larval density could involve physical contact, hydromechanical disturbance, or chemical exudates. Sensing of disturbance is a common method of prey and predator detection in planktonic organisms, and the frequency of disturbance, even in the absence of direct 
contact, could provide indicators of overall density or even species identity (Visser 2001). Morphological plasticity of larvae is sensitive to algal exudates (Miner 2007) and could similarly respond to those of zooplankton (Metaxas \& Burdett-Coutts 2006). Chemical cues from conspecifics, for example, were sufficient to trigger a plastic response in bullfrog tadpoles (Guariento et al. 2015). How such signals are transduced into a morphological response is unexplored. Thyroid hormone derived exogenously from algae has been proposed to regulate the plastic response to food levels in echinoid larvae (Heyland \& Hodin 2004), involving changes in dopamine signaling (Adams et al. 2011) and gene expression (Carrier et al. 2015). It is possible that a stress response to crowding could alter a hormonal pathway like dopamine signaling in a similar manner (Moriam \& Sobhani 2013). Likewise, the difference in response of stomach length to conspecific and heterospecific larvae we observed could involve differential exposure to thyroid hormone, which is produced by larvae of $D$. excentricus, as exposure to thyroid hormone can induce a reduction in stomach growth (Heyland \& Hodin 2004).

While this study is the first to demonstrate an effect of density on plasticity in marine invertebrate larvae, our survey of previous studies makes clear that there has been little effort to standardize culture density or to test for such an effect. The distribution of larval densities across experiments was strongly modal around $1 \mathrm{ml}^{-1}$, possibly by convention, but ranged over nearly 2 orders of magnitude. In the only example of variation within a publication, BoidronMetairon (1988) studied 2 echinoid species, each cultured at a different density. Consistent with our results, $D$. excentricus cultured at our high density level $\left(0.25 \mathrm{ml}^{-1}\right)$ expressed plasticity of arm length that was greater in magnitude and duration than did Lytechinus variegatus cultured at a density $\left(0.067 \mathrm{ml}^{-1}\right)$, closer to our low density. In addition to species differences, however, the experiments on these 2 species differed in other aspects of methodology, including how food limitation was imposed, leaving uncertain whether density is implicated in the interspecific difference. In our survey, we did not find an association between culture density and plasticity; however, given (1) lack of resolution of where density has an appreciable effect on plasticity, (2) a lack of studies that used densities as low as ours, and (3) the relatively small number of studies that have reported a lack of plasticity (possibly as a result of publication bias), data from previous studies might not be able to resolve this question in an informative range of densities. Furthermore, effects of density could be obscured in interspecific comparisons by other factors, including egg size, latitude, and larval form, that contribute to patterns of plastic expression (Podolsky \& McAlister 2005, McAlister 2007, Reitzel \& Heyland 2007, Soars et al. 2009). Future work should try to resolve intraspecific patterns of density dependence in the expression of plasticity.

The ecological and evolutionary significance of the effect we identified depends on the frequency and duration of larval exposure to different densities in nature. For many species, synchronous spawning is the greatest source of high larval density (Christy \& Stancyk 1982), although cohort persistence can depend on bathymetry, water movement, and predation. Adults of $D$. excentricus live in dense aggregations that spawn synchronously, resulting in larval cohorts that advect and diffuse on variable time scales (Emlet 1986). Bos et al. (2006) measured peaks of bivalve larval density at 10 locations around the North Sea as high as $0.4 \mathrm{ml}^{-1}$, but found that cohorts had typically dissipated within 1 or 2 weekly samples. Jørgensen (1981) began tracking a cohort of larvae of the mussel Mytilus edulis in a Danish fjord when surface densities were about $3.4 \mathrm{ml}^{-1}$. Estimating from their data, densities stayed above our high density of $0.25 \mathrm{ml}^{-1}$ for about $17 \mathrm{~d}$ and above our low density of $0.05 \mathrm{ml}^{-1}$ for $27 \mathrm{~d}$. Whereas Bos et al. (2006) estimated that larval nutritional needs were not met by their food supply (a requisite for competition), Jørgensen (1981) found that growth in the field was not different from that under satiating conditions in the lab. More generally, Strathmann (1996) concluded that conspecific larvae rarely remain at high enough density for long enough and with clearance capabilities necessary to significantly impact their food supply. In light of these temporal patterns, it is notable that plasticity in laboratory culture is often most apparent during early stages (Podolsky \& McAlister 2005) before mortality and advection would dilute high initial densities in the field.

The potential for larvae to experience sustained high densities as part of larger planktonic assemblages is less clear. Field zooplankton densities in our literature survey were typically several orders of magnitude below those used in laboratory culture. However, aggregate densities from surveys could be on a spatial scale too large to characterize small-scale interactions (Pinel-Alloul 1995). If biotic or abiotic forces concentrate zooplankton relative to phytoplankton (Blukacz et al. 2010) then competitive interactions and resource limitation could increase in patches (Bos et al. 2006). It is therefore important to 
consider by what factor and mechanism densities of plankton could be elevated above aggregate estimates. Using continuous high-resolution counting, Trudnowska et al. (2016) measured plankton concentrations in dense patches that were up to 17 times higher than background; mesozooplankton were concentrated mainly in association with water density fronts. Similarly, Hofer et al. (2017) found stalked barnacle larvae concentrated in river plumes by an order of magnitude relative to background. Sampling on a larger scale, Morgan et al. (2005) found that plankton biomass was up to 47 times higher in fronts than in neighboring waters. In contrast, using highfrequency sampling Molinero et al. (2008) found that, while plankton was taxonomically variable, total densities remained consistent. Even if patch densities are sometimes an order of magnitude or more above background, the question is whether larvae experience such patches frequently and for long enough to provide a reliable cue for adaptive plasticity (Padilla \& Adolph 1996). The same physical processes that concentrate plankton, for example, can also lead patches to be highly transient (Mitchell et al. 2008, Flierl \& Woods 2015), reducing the likelihood of a coherent signal. As a result, densities that a larva will typically encounter may remain orders of magnitude lower than those at which plasticity has been demonstrated and at which we no longer detected it. In light of these observations, laboratory studies of plasticity that have used high density cultures should be interpreted with caution, and tests of the significance of plasticity should be done explicitly within a natural range of densities (e.g. Relyea 2004).

This caveat applies broadly to laboratory culture of larvae at unnaturally high densities (Scheltema 1986). For example, Johnson \& Shanks (1997) identified an analogous artifact in studies of larvae as prey: substantial predation seen at typical culture densities was eliminated at lower, field-relevant densities. They attributed this loss of predation to changes in behavior and capture success when prey were naturally sparse. Potentially even more problematic is the regular culture of larvae at extremely high densities for molecular or physiological measurements, where crowding could alter physiological state or macromolecule expression (Nga et al. 2005, Salas-Leiton et al. 2010, Gao et al. 2018). Because laboratory experiments always involve an interaction between treatment conditions and holding conditions, the ecological relevance of culture conditions is critical for interpreting outcomes. In any study where outcomes could be affected by interactions among individuals or by a change in physical conditions that results from crowding (e.g. high $\mathrm{CO}_{2}$ or ammonia), culture density should be treated as a critical aspect of experimental design, taking account of the organism's natural history (e.g. synchronous spawning). High larval densities that have been typical of laboratory experiments may in fact prove useful for studying plankton dynamics in disturbed systems, as elevated densities are a common result of eutrophication (e.g. Selifonova 2008, Garcia \& Bonel 2014).

A related caveat applies when morphology is used to infer the condition of field-collected larvae. Comparisons between seasons or locations, for example, have used larval morphology as an indicator of relative food limitation (Fenaux et al. 1994, Miller \& Emlet 1999). Given our finding that meroplankton or whole zooplankton density could influence larval morphology, future studies should take account of the densities and composition of the communities from which animals are collected for comparisons. Klinzing \& Pechenik (2000) listed other factors identified from lab experiments that can cloud the interpretation of morphology in field-collected larvae. More generally, as Scheltema (1986, p. 295) cautioned, 'it seems unwise to extrapolate uncritically the quantitative results from such standing cultures to natural populations.'

Acknowledgements. We thank R. Strathmann and D. Grünbaum for help with experimental design; S. Gilman, S. Koch, and A. Welch for statistical support; J. Hodin and 2 anonymous reviewers for helping significantly to improve the manuscript; and the director and staff of the Friday Harbor Laboratories for research space and logistical support. The project was supported by National Science Foundation award OCE-0621467 to R.D.P. This is contribution 507 of the Grice Marine Laboratory, College of Charleston.

\section{LITERATURE CITED}

Adams DK, Sewell MA, Angerer RC, Angerer LM (2011) Rapid adaptation to food availability by a dopaminemediated morphogenetic response. Nat Commun 2:592

Allen JD (2008) Size-specific predation on marine invertebrate larvae. Biol Bull (Woods Hole) 214:42-49

Araujo HMP, Nascimento-Vieira DA, Neumann-Leitao S, Schwamborn R, Lucas APO, Alves JPH (2008) Zooplankton community dynamics in relation to the seasonal cycle and nutrient inputs in an urban tropical estuary in Brazil. Braz J Biol 68:751-762

Avila TR, Pedrozo CS, Bersano JGF (2009) Temporal variation of the zooplankton from Tramandai Beach, RS, southern Brazil, with emphasis on Copepoda. Iheringia Ser Zool 99:18-26

Bertram DF, Strathmann RR (1998) Effects of maternal and larval nutrition on growth and form of planktotrophic larvae. Ecology (Wash DC) 79:315-327

*Blukacz EA, Sprules WG, Shuter BJ, Richards JP (2010) Evaluating the effect of wind-driven patchiness on 
trophic interactions between zooplankton and phytoplankton. Limnol Oceanogr 55:1590-1600

Boidron-Metairon IC (1988) Morphological plasticity in laboratory-reared echinoplutei of Dendraster excentricus (Eschscholtz) and Lytechinus variegatus (Lamarck) in response to food conditions. J Exp Mar Biol Ecol 119: 31-41

Bos OG, Hendriks IE, Strasser M, Dolmer P, Kamermans P (2006) Estimation of food limitation of bivalve larvae in coastal waters of north-western Europe. J Sea Res 55: 191-206

Bouchard SS, O'Leary CJ, Wargelin LJ, Charbonnier JF, Warkentin KM (2016) Post-metamorphic carry-over effects of larval digestive plasticity. Funct Ecol 30:379-388

Burke RD (1981) Structure of the digestive tract of the pluteus larva of Dendraster excentricus (Echinodermata Echinoida). Zoomorphology (Berl) 98:209-226

Burns JH, Strauss SY (2012) Effects of competition on phylogenetic signal and phenotypic plasticity in plant functional traits. Ecology 93:S126-S137

Byrne M, Sewell MA, Prowse TAA (2008) Nutritional ecology of sea urchin larvae: influence of endogenous and exogenous nutrition on echinopluteal growth and phenotypic plasticity in Tripneustes gratilla. Funct Ecol 22: 643-648

Carrier TJ, King BL, Coffman JA (2015) Gene expression changes associated with the developmental plasticity of sea urchin larvae in response to food availability. Biol Bull (Woods Hole) 228:171-180

Chester A, Damkaer D, Dey D, Heron G, Larrance J (1980) Plankton of the Strait of Juan de Fuca, 1976-77. Interagency Energy/Environment R\&D Program Report, EPA600/7-80-032. US Environmental Protection Agency, Office of Environmental Engineering and Technology, Washington, DC

Christy JH, Stancyk SE (1982) Timing of larval production and flux of invertebrate larvae in a well-mixed estuary. In: Kennedy V (ed) Estuarine comparisons. Academic Press, New York, NY, p 489-503

Civelek CV, Daigle RM, Metaxas A (2013) Effects of temperature on larval swimming patterns regulate vertical distribution relative to thermoclines in Asterias rubens. J Exp Mar Biol Ecol 445:1-12

Cornils A, Schnack-Schiel SB, Al-Najjar T, Badran MI, Rasheed M, Manasreh R, Richter C (2007) The seasonal cycle of the epipelagic mesozooplankton in the northern Gulf of Aqaba (Red Sea). J Mar Syst 68:278-292

Cronin TW, Forward JRB (1986) Vertical migration cycles of crab larvae and their role in larval dispersal. Bull Mar Sci 39:192-201

D'Elbee J, Castel J (1995) Spatiotemporal evolution of zooplankton in Arcachon Bay-the role of environmental factors. Cah Biol Mar 36:33-45

Defren-Janson K, Schnack-Schiel SB, Richter C (1999) Mesozooplankton communities in the Magellan region. Sci Mar 63:43-50

DeWitt TJ, Sih A, Wilson DS (1998) Costs and limits of phenotypic plasticity. Trends Ecol Evol 13:77-81

DeWolf P (1973) Distribution and dispersal of barnacle larvae. Neth J Sea Res 6:1-112

Eckert GL (1995) A novel larval feeding strategy of the tropical sand dollar, Encope michelini (Agassiz): adaptation to food limitation and an evolutionary link between planktotrophy and lecithotrophy. J Exp Mar Biol Ecol 187:103-128
Eckert GL (1998) Larval development, growth and morphology of the sea urchin Diadema antillarum. Bull Mar Sci 63:443-451

Emlet RB (1986) Larval production, dispersal, and growth in a fjord: a case study on larvae of the sand dollar Dendraster excentricus. Mar Ecol Prog Ser 31:245-254

* Fenaux L, Strathmann MF, Strathmann RR (1994) Five tests of food-limited growth of larvae in coastal waters by comparison of rates of development and form of echinoplutei. Limnol Oceanogr 39:84-98

Flierl GR, Woods NW (2015) Copepod aggregations: influences of physics and collective behavior. J Stat Phys 158: 665-698

Folt CL, Burns CW (1999) Biological drivers of zooplankton patchiness. Trends Ecol Evol 14:300-305

Futuyma DJ, Moreno G (1988) The evolution of ecological specialization. Annu Rev Ecol Syst 19:207-233

*Gao XL, Li X, Shi C, Wu FC, Song CB, Liu Y (2018) Effects of stocking density on growth, metabolism, and energy budget of Haliotis discus hannai Ino. Aquaculture 483: 84-95

Garcia MD, Bonel N (2014) Environmental modulation of the plankton community composition and size-structure along the eutrophic intertidal coast of the Rio de la Plata estuary, Argentina. J Limnol 73:562-573

Garcia E, Clemente S, Lopez C, McAlister JS, Hernandez JC (2015) Ocean warming modulates the effects of limited food availability on Paracentrotus lividus larval development. Mar Biol 162:1463-1472

George SB (1999) Egg quality, larval growth and phenotypic plasticity in a forcipulate seastar. J Exp Mar Biol Ecol 237:203-224

Guariento RD, Carneiro LS, Esteves FA, Jorge JS, Caliman A (2015) Conspecific density affects predator-induced prey phenotypic plasticity. Ecosphere 6:106

* Hart MW (1996) Variation in suspension feeding rates among larvae of some temperate, eastern Pacific echinoderms. Invertebr Biol 115:30-45

Hart MW, Scheibling RE (1988) Comparing shapes of echinoplutei using principal components analysis, with an application to larvae of Strongylocentrotus droebachiensis. In: Burke RD, Mladenov PV, Lamber P, Parsley RL (eds) Echinoderm biology. AA Balkema, Rotterdam, p 277-284

*Hart MW, Strathmann RR (1994) Functional consequences of phenotypic plasticity in echinoid larvae. Biol Bull (Woods Hole) 186:291-299

* Heyland A, Hodin J (2004) Heterochronic developmental shift caused by thyroid hormone in larval sand dollars and its implications for phenotypic plasticity and the evolution of nonfeeding development. Evolution 58:524-538

*Hodin J, Lutek K, Heyland A (2016) A newly identified leftright asymmetry in larval sea urchins. R Soc Open Sci 3: 160139

Hofer J, Muniz C, Weidberg N, Garcia-Florez L, Acuna JL (2017) High densities of stalked barnacle larvae (Pollicipes pollicipes) inside a river plume. J Plankton Res 39: 316-329

Hollander J (2008) Testing the grain-size model for the evolution of phenotypic plasticity. Evolution 62:1381-1389

Holm S (1979) A simple sequentially rejective multiple test procedure. Scand J Stat 6:65-70

*Hsieh HL, Fan LF, Chen CP, Wu JT, Liu WC (2010) Effects of semidiurnal tidal circulation on the distribution of holoand meroplankton in a subtropical estuary. J Plankton 
Res 32:829-841

Hunt BPV, Hosie GW (2006) The seasonal succession of zooplankton in the Southern Ocean south of Australia. Part I: The seasonal ice zone. Deep Sea Res I 53:1182-1202

Hunt BPV, Pakhomov EA, McQuaid CD (2002) Community structure of mesozooplankton in the Antarctic polar frontal zone in the vicinity of the Prince Edward Islands (Southern Ocean): small-scale distribution patterns in relation to physical parameters. Deep Sea Res II 49: 3307-3325

Johnson KB, Shanks AL (1997) The importance of prey densities and background plankton in studies of predation on invertebrate larvae. Mar Ecol Prog Ser 158:293-296

Jørgensen CB (1981) Mortality, growth, and grazing impact of a cohort of bivalve larvae, Mytilus edulis L. Ophelia 20:185-192

Klinzing MSE, Pechenik JA (2000) Evaluating whether velar lobe size indicates food limitation among larvae of the marine gastropod Crepidula fornicata. J Exp Mar Biol Ecol 252:255-279

Koettker AG, Lopes RM (2013) Meroplankton spatial structure and variability on Abrolhos Bank and adjacent areas, with emphasis on brachyuran larvae. Cont Shelf Res 70:97-108

Levins R (1968) Evolution in changing environments. Princeton University Press, Princeton, NJ

Lonsdale DJ, Coull BC (1977) Composition and seasonality of zooplankton of North Inlet, South Carolina USA. Chesap Sci 18:272-283

Marques SC, Azeiteiro UM, Martinho F, Viegas I, Pardal MA (2009) Evaluation of estuarine mesozooplankton dynamics at a fine temporal scale: the role of seasonal, lunar and diel cycles. J Plank Res 31:1249-1263

McAlister JS (2007) Egg size and the evolution of phenotypic plasticity in larvae of the echinoid genus Strongylocentrotus. J Exp Mar Biol Ecol 352:306-316

McAlister JS (2008) Evolutionary responses to environmental heterogeneity in Central American echinoid larvae: plastic versus constant phenotypes. Evolution 62: 1358-1372

McEdward LR (1986) Comparative morphometrics of echinoderm larvae. II. Larval size, shape, growth, and the scaling of feeding and metabolism in echinoplutei. J Exp Mar Biol Ecol 96:267-286

McEdward LR, Herrera JC (1999) Body form and skeletal morphometrics during larval development of the sea urchin Lytechinus variegatus Lamarck. J Exp Mar Biol Ecol 232:151-176

Meidel SK, Scheibling RE, Metaxas A (1999) Relative importance of parental and larval nutrition on larval development and metamorphosis of the sea urchin Strongylocentrotus droebachiensis. J Exp Mar Biol Ecol 240:161-178

Menendez MC, Dutto MS, Piccolo MC, Hoffmeyer MS (2012) The role of the seasonal and semi-diurnal tidal cycle on mesozooplankton variability in a shallow mixed estuary (Baha Blanca, Argentina). ICES J Mar Sci 69: 389-398

Metaxas A, Burdett-Coutts V (2006) Response of invertebrate larvae to the presence of the ctenophore Bolinopsis infundibulum, a potential predator. J Exp Mar Biol Ecol 334:187-195

Metaxas A, Young CM (1998) Responses of echinoid larvae to food patches of different algal densities. Mar Biol 130: 433-445

Miller BA, Emlet RB (1999) Development of newly meta- morphosed juvenile sea urchins (Strongylocentrotus franciscanus and $S$. purpuratus): morphology, the effects of temperature and larval food ration, and a method for determining age. J Exp Mar Biol Ecol 235:67-90

Miner BG (2005) Evolution of feeding structure plasticity in marine invertebrate larvae: a possible trade-off between arm length and stomach size. J Exp Mar Biol Ecol 315: $117-125$

Miner BG (2007) Larval feeding structure plasticity during pre-feeding stages of echinoids: Not all species respond to the same cues. J Exp Mar Biol Ecol 343:158-165

* Miner BG, Vonesh JR (2004) Effects of fine grain environmental variability on morphological plasticity. Ecol Lett 7:794-801

Mitchell JG, Yamazaki H, Seuront L, Wolk F, Li H (2008) Phytoplankton patch patterns: seascape anatomy in a turbulent ocean. J Mar Syst 69:247-253

* Molinero JC, Ibanez F, Souissi S, Bosc E, Nival P (2008) Surface patterns of zooplankton spatial variability detected by high frequency sampling in the NW Mediterranean. Role of density fronts. J Mar Syst 69:271-282

Morgan AD (2008) The effect of food availability on phenotypic plasticity in larvae of the temperate sea cucumber Australostichopus mollis. J Exp Mar Biol Ecol 363:89-95

* Morgan CA, De Robertis A, Zabel RW (2005) Columbia River plume fronts. I. Hydrography, zooplankton distribution, and community composition. Mar Ecol Prog Ser 299:19-31

Moriam S, Sobhani ME (2013) Epigenetic effect of chronic stress on dopamine signaling and depression. Genet Epigenet 5:11-16

*Neumann-Leitao S, Sant'anna EME, Gusmao LMD, Do Nascimento-Vieira DA, Paranagua MN, Schwamborn R (2008) Diversity and distribution of the mesozooplankton in the tropical Southwestern Atlantic. J Plankton Res 30: 795-805

Nga BT, Lurling M, Peeters E, Roijackers R, Scheffer M, Nghia TT (2005) Chemical and physical effects of crowding on growth and survival of Penaeus monodon Fabricius post-larvae. Aquaculture 246:455-465

Okazaki K (1975) Normal development to metamorphosis. In: Czihak G (ed) The sea urchin embryo. Springer, Berlin, p 177-232

Padilla DK, Adolph SD (1996) Plastic inducible morphologies are not always adaptive: the importance of time delays in a stochastic environment. Evol Ecol 10:105-117

* Pakhomov EA, Froneman PW (2004) Zooplankton dynamics in the eastern Atlantic sector of the Southern Ocean during the austral summer 1997/1998-Part 1: Community structure. Deep Sea Res II 51:2599-2616

Pennington JT, Emlet RB (1986) Ontogenetic and diel vertical migration of a planktonic echinoid larva, Dendraster excentricus (Eschscholtz): occurrence, causes, and probable consequences. J Exp Mar Biol Ecol 104:69-95

*Pfennig DW, Pfennig KS (2010) Character displacement and the origins of diversity. Am Nat 176(Suppl 1):S26-S44

* Phillips NE (2011) Where are larvae of the vermetid gastropod Dendropoma maximum on the continuum of larval nutritional strategies? Mar Biol 158:2335-2342

* Pinel-Alloul B (1995) Spatial heterogeneity as a multiscale characteristic of zooplankton community. Hydrobiologia 300:17-42

* Podolsky RD, McAlister JS (2005) Developmental plasticity in Macrophiothrix brittlestars: Are morphologically convergent larvae also convergently plastic? Biol Bull 
(Woods Hole) 209:127-138

Pörtner H, Dupont S, Melzner F, Storch D, Thorndyke M (2010) Laboratory experiments and benthic mesocosm studies. In: Riebesell U, Fabry V, Hansson L, Gattuso JP (eds) Guide to best practices for ocean acidification research and data reporting. Publications Office of the European Union, Luxembourg, p 167-180

Primo AL, Azeiteiro UM, Marques SC, Martinho F, Pardal MA (2009) Changes in zooplankton diversity and distribution pattern under varying precipitation regimes in a southern temperate estuary. Estuar Coast Shelf Sci 82: 341-347

Purcell JE (2003) Predation on zooplankton by large jellyfish, Aurelia labiata, Cyanea capillata and Aequorea aequorea, in Prince William Sound, Alaska. Mar Ecol Prog Ser 246:137-152

Reitzel AM, Heyland A (2007) Reduction in morphological plasticity in echinoid larvae: relationship of plasticity with maternal investment and food availability. Evol Ecol Res 9:109-121

Relyea RA (2004) Fine-tuned phenotypes: tadpole plasticity under 16 combinations of predators and competitors. Ecology 85:172-179

Relyea RA, Auld JR (2005) Predator- and competitorinduced plasticity: how changes in foraging morphology affect phenotypic trade-offs. Ecology 86:1723-1729

* Rodriguez F, Fernandez E, Head RN, Harbour DS, Bratbak G, Heldal M, Harris RP (2000) Temporal variability of viruses, bacteria, phytoplankton and zooplankton in the western English Channel off Plymouth. J Mar Biol Assoc UK 80:575-586

Rovinsky $A B$, Adiwidjaja $H$, Yakhnin VZ, Menzinger M (1997) Patchiness and enhancement of productivity in plankton ecosystems due to the differential advection of predator and prey. Oikos 78:101-106

Salas-Leiton E, Anguis V, Martín-Antonio B, Crespo D and others (2010) Effects of stocking density and feed ration on growth and gene expression in the Senegalese sole (Solea senegalensis): potential effects on the immune response. Fish Shellfish Immunol 28:296-302

Scheiner SM, Gomulkiewicz R, Holt RD (2015) The genetics of phenotypic plasticity. XIV. Coevolution. Am Nat 185: 594-609

Scheltema RS (1986) On dispersal and planktonic larvae of benthic invertebrates: an eclectic overview and summary of problems. Bull Mar Sci 39:290-322

Selifonova ZP (2008) Taxonomic composition and interannual variations in numerical density of meroplankton in the Sea of Azov. Biol Morya (Vladivost) 34:311-317

Sewell MA, Cameron MJ, McArdle BH (2004) Developmental plasticity in larval development in the echinometrid

Editorial responsibility: Emily Carrington,

Seattle, Washington, USA sea urchin Evechinus chloroticus with varying food ration. J Exp Mar Biol Ecol 309:219-237

Soars NA, Prowse TAA, Byrne M (2009) Overview of phenotypic plasticity in echinoid larvae, 'Echinopluteus transversus' type vs. typical echinoplutei. Mar Ecol Prog Ser 383:113-125

K Stevens CJ, Pakhomov EA, Robinson KV, Hall JA (2015) Mesozooplankton biomass, abundance and community composition in the Ross Sea and the Pacific sector of the Southern Ocean. Polar Biol 38:275-286

Strathmann MF (1987) Reproduction and development of marine invertebrates of the northern Pacific coast. University of Washington Press, Seattle, WA

Strathmann RR (1996) Are planktonic larvae of marine benthic invertebrates too scarce to compete within species? Oceanol Acta 19:399-407

* Strathmann RR, Fenaux L, Strathmann MF (1992) Heterochronic developmental plasticity in larval sea urchins and its implications for evolution of nonfeeding larvae. Evolution 46:972-986

Strathmann RR, Fenaux L, Sewell AT, Strathmann MF (1993) Abundance of food affects relative size of larval and postlarval structures of a molluscan veliger. Biol Bull (Woods Hole) 185:232-239

F Sun XJ, Li Q (2013) The effect of food availability on development and phenotypic plasticity in larvae of the sea cucumber (Apostichopus japonicus). Invertebr Reprod Dev 57:255-263

Takahashi KT, Hosie GW, Kitchener JA, McLeod DJ, Odate T, Fukuchi M (2010) Comparison of zooplankton distribution patterns between four seasons in the Indian Ocean sector of the Southern Ocean. Polar Sci 4:317-331

* Thompson PA, Bonham PI, Swadling KM (2008) Phytoplankton blooms in the Huon Estuary, Tasmania: top-down or bottom-up control? J Plankton Res 30:735-753

*Trudnowska E, Gluchowska M, Beszczynska-Möller A, Blachowiak-Samolyk K, Kwasniewski S (2016) Plankton patchiness in the Polar Front region of the West Spitsbergen Shelf. Mar Ecol Prog Ser 560:1-18

Tseng LC, Dahms HU, Hung JJ, Chen QC, Hwang JS (2011) Can different mesh sizes affect the results of copepod community studies? J Exp Mar Biol Ecol 398:47-55

Vaughn D (2007) Predator-induced morphological defenses in marine zooplankton: a larval case study. Ecology 88: 1030-1039

Visser AW (2001) Hydromechanical signals in the plankton. Mar Ecol Prog Ser 222:1-24

*Wolfe K, Graba-Landry A, Dworjanyn SA, Byrne M (2015) Larval phenotypic plasticity in the boom-and-bust crown-of-thorns seastar, Acanthaster planci. Mar Ecol Prog Ser 539:179-189

Submitted: January 8, 2018; Accepted: March 21, 2018

Proofs received from author(s): April 8, 2018 